\title{
PROFIL DESA TAMBAK SUMUR UNTUK TUJUAN PEMBANGUNAN BERKELANJUTAN
}

\author{
Robby Fauji , Dwi Epty 2 , Dexi Triadinda \\ PROGRAM STUDI MANAJEMEN FAKULTAS EKONOMI DAN BISNIS \\ UNIVERSITAS BUANA PERJUANGAN KARAWANG \\ robby.fauji@ubpkarawang.ac.id \\ dwi.epty@ubpkarawang.ac.id \\ dexidinda@ubpkarawang.ac.id
}

\begin{abstract}
Abstrak
Program KKN yang dilaksanakan oleh Universitas Buana Perjuangan Karawang adalah merupakan bentuk penegasan loyalitas dan solidaritas Universitas Buana Perjuangan Karawang untuk mewujudkan Visi dan Misinya. Oleh karena itu, program KKN yang dilaksanakan oleh Universitas Buana Perjuangan Karawang diharapkan dapat lebih meningkatkan sikap mahasiswa tentang empati, kepedulian, kerjasama mahasiswa secara multidisipliner dan kontribusi daya saing, baik secara regional maupun nasional, serta mendorong terciptanya Learning Community.

Desa Tambaksumur merupakan salah satu daerah persawahan yang meluas. Oleh karena itu, kelestarian alam merupakan salahsatu masalah yang selalu menjadi pertimbangan pokok dalam upaya pengembangan wilayah yang berada didekat laut. Desa Tambaksumur termasuk ke dalam kawasan persawahan, yang ditunjang dengan aliran air yang cukup. Sebagai daerah yang berada di dekat laut Sarakan, Desa Tambaksumur mempunyai beberapa sumber air yang tak pernah kering walaupun dalam musim kemarau. Sumber-sumber air itu, antara lain terdapat irigasi yang teraliri dari sungai citarum. Posisi geografik Desa Tambaksumur berada pada koordinator bujur 107.265666 dan koordinator lintang -6.002484. Luas wilayah Desa Tambaksumur 2610 hektar.
\end{abstract}

Kata Kunci : Desa Tambak Sumur,kuliah kerja nyata $(\mathrm{KKN}) 2020$ 


\section{PENDAHULUAN}

Kuliah Kerja Nyata $(\mathrm{KKN})$ merupakan artikulasi dari semangat pengabdian kepada masyarakat yang tidak lepas dari esensi penelitian dan pendidikan. Pengabdian kepada masyarakat sebagai dasar utama adanya KKN tidak serta merta terlepas dari esensi penelitian dan pendidikan. Karenanya, struktur-struktur kegiatan KKN dengan fokus utama pengabdian kepada masyarakat tetap berada pada koridor kedua esensi tersebut.

Kuliah Kerja Nyata (KKN), pertama kali dilaksanakan di Universitas Gadjah Mada pada tahun 1971 dan masih dilaksanakan sampai sekarang. Adapun perkembangan periode pelaksanaan KKN yang dilaksanakan oleh Universitas Gadjah Mada, adalah : pertama periode perintisan (1971-1976); kedua periode peralihan (1977-1979); ketiga periode pemantapan (1979-1990); keempat periode pengembangan (1990-1997); kelima periode transformasi (1998-2005); keenam periode KKN tematik kontekstual (20042006); Dan ketujuh periode KKN-PPM (2006-Sekarang). KKN adalah wahana bagi mahasiswa untuk memberikan bantuan kepada masyarakat perdesaan dalam memecahkan persoalan pembangunan yang kemudian dijadikan sebagai kegiatan intrakulikuler yang wajib diikuti oleh mahasiswa (menjadi bagian dari kurikulum).

Program KKN yang dilaksanakan oleh Universitas Buana Perjuangan Karawang dengan tema Profil Desa Berkelanjutan merupakan bentuk penegasan loyalitas dan solidaritas Universitas Buana Perjuangan Karawang untuk mewujudkan Visi dan Misinya. Oleh karena itu, program KKN yang dilaksanakan oleh Universitas Buana Perjuangan Karawang diharapkan dapat lebih meningkatkan sikap mahasiswa tentang empati, kepedulian, kerjasama mahasiswa secara multidisipliner dan kontribusi daya saing, baik secara regional maupun nasional, serta mendorong terciptanya Learning Community.

Desa Tambaksumur merupakan salah satu daerah persawahan yang meluas. Oleh karena itu, kelestarian alam merupakan salahsatu masalah yang selalu menjadi pertimbangan pokok dalam upaya pengembangan wilayah yang berada didekat laut. Desa Tambaksumur termasuk ke dalam kawasan persawahan, yang ditunjang dengan aliran air yang cukup. Sebagai daerah yang berada di dekat laut Sarakan, Desa Tambaksumur mempunyai beberapa sumber air yang tak pernah kering walaupun dalam musim kemarau. Sumber-sumber air itu, antara lain terdapat irigasi yang teraliri dari sungai 
citarum. Secara umum, posisi geografik Desa Tambaksumur berada pada koordinator bujur 107.265666 dan koordinator lintang -6.002484. Luas wilayah Desa Tambaksumur 2610 hektar.

Perkembangan desa tambaksumur dalam segi kesehatan fasilitasnya sudah cukup lengkap dibandingkan dari tahun sebelumnya contohnya seperti posyandu, kampung KB. Dalam segi pendidikan di desa tambaksumur juga sudah mulai bertambah, seperti paud yang sebelumnya berjumlah 3 paud dan tahun ini bertambah 2 paud dan sekarang berjumlah 5 paud. dan dalam segi perekonomian sudah mulai membaik dari pada tahun sebelumnya, contohnya seperti rumah yang tidak layak huni sudah diperbaiki. Aliran menjadi sangat baik sehingga membantu perekonomian petani untuk mengairi sawah dan empang agar petani lebih mudah mendapatkan hasil yang cukup baik. 


\section{METODE}

\section{A. Metode Pendekatan Pendekatan}

Pendekatan yang akan diterapkan dalam program pendampingan pengembangan UMKM yaitu metode pelatihan kewirausahaan usaha ikan bandeng, dengan berbagai kegiatan antara lain :

1. Metode workshop Kewirausahaan, manajemen bisnis, menajamen keuangan, produksi, dan pemasaran berbasis tekonologi bagi pelaku umkm untuk dibekali aspek teknis dalam membuat perencanaan usaha yang akan dikembangankan oleh umkm. Kegiatan ini diakukan seminggu dua kali secara daring dengan narasumber dari dosen manajemen.

2. Melakukan pembimbingan dan pendampingan teknis usaha kepada UMKM terpilih, yang difokuskan pada upaya meningkatkan kapasitas UMKM dalam bidang perencanaan usaha (business plan), manajemen bisnis, pengelolaan usaha, proses produksi, dan manajemen keuangan. 


\section{HASIL DAN PEMBAHASAN}

Berdasarkan data yang kami terima dari pihak desa Tambaksumur dan data yang kami dapat melalui Prodeskel desa Tambaksumur. Kami pun membagi beberapa aspek perkembangan bagi desa Tambaksumur, yaitu :

\section{Perkembangan Penduduk}

Pada tahun 2019 Desa Tambaksumur memiliki jumlah penduduk 7.971 orang diantaranya adalah 3794 orang Laki-laki dan 4177 orang Perempuan. Sedangkan pada tahun 2020 jumlah penduduk desa Tambaksumur adalah 7.952 diantaranya adalah 3769 orang Laki-laki dan 4183 orang Perempuan. Yang artinya perkembangan penduduk pada desa Tambaksumur mengalami penurunan sebesar $0,002 \%$ penduduk.

\section{Ekonomi Masyarakat}

Ekonomi masyarakat setempat bergantung kepada sumber pertanian. Karena Tambaksumur memiliki luas tanah persawahan sebesar $620.000 \mathrm{Ha}$ dan memiliki 3.080 Kepala keluarga yang bermata-pencarian pada pertanian.

\section{Produk Domestik}

Produk domestik yang menjadi sumber mata pencarian oleh penduduk setempat adalah jenis tanaman Padi. Hasil Produksi mencapai 5 Ton/Ha.

\section{Aset Ekonomi Masyarakat}

Berdasarkan data, sejumlah 877 Orang tidak memiliki tanah, dan ada beberapa penduduk yang memiliki tanah dengan kisaran beragam. Untuk transportasi umum terdapat 30 Unit Ojek. Terdapat 4 orang memiliki penggilingan padi, 20 orang memiliki traktor, 4 orang memiliki pabrik pengolahan hasil pertanian, 5 orang memiliki alat produksi dan pengolah hasil industri kerajinan keluarga skala kecil dan menengah dan 23 orang memiliki alat produksi dan pengolahan hasil industri migas.

\section{Kesehatan Masyarakat}

- Kualitas Ibu Hamil, berdasarkan data yang terdapat pada Prodeskel pada tahun 2020 jumlah ibu hamil adalah 125 orang, ibu hamil yang memeriksa kandungan ke posyandu berjumlah 56 orang, 100 orang 
periksa di bidan praktek. Jumlah ibu melahirkan 120 orang, 20 untuk jumlah ibu nifas dan 120 ibu nifas yang hidup.

- Kualitas Bayi, terdapat 120 bayi lahir dan semuanya hidup dengan selamat.

- Kualitas Persalinan, terdapat 3 Unit Rumah bersalin dan 3 Unit tempat persalinan praktek bidan. Jumlah persalinan yang ditolong bidan mencapai 120 tindakan.

- Cakupan imunisasi

Tabel 3.1 Cakupan Imunisasi

\begin{tabular}{|l|c|}
\hline Jumlah Bayi usia 2 bulan & $\begin{array}{c}30 \\
\text { Orang }\end{array}$ \\
\hline Jumlah bayi 2 bulan Imunisasi DPT-1, BCG dan & 25 \\
Polio -1 & rang \\
\hline Jumlah bayi usia 3 bulan & 20 \\
& Orang \\
\hline Jumlah bayi 3 bulan yang imunisasi DPT-2 dan & 20 \\
Polio-2 & Orang \\
\hline Jumlah bayi usia 4 bulan & 18 \\
\hline Jumlah bayi 4 bulan yang imunisasi DPT-2 dan & Orang \\
Polio-2 & Orang \\
\hline Jumlah bayi 9 bulan & 15 \\
& Orang \\
\hline Jumlah bayi 9 bulan yang imunisasi DPT-2 dan & 10 \\
Polio-2 & Orang \\
\hline Jumlah bayi yang sudah imunisasi cacar & 20 \\
\hline Orang \\
\hline
\end{tabular}

Sumber : Prosdekel Tambak Sumur 2020

Permasalahan berdasarkan data di Prodeskel adalah, kecilnya pendapatan bagi sektor pertanian per rumah tangga yaitu Rp.50.000. Hal ini tentunya merupakan masalah yang dapat dikatakan besar, padahal Karawang merupakan kota lumbung padi yang seharusnya 
dapat mensejahterakan masyarakat dari kelebihan yang ada. Kemudian sangat sedikitnya taman bacaan yang dimiliki oleh desa Tambaksumur yaitu hanya 1 unit. Permasalahan selanjutnya adalah data desa pertahun yang tidak lengkap di prodeskel. Lalu menurut data yang kami dapat terdapat 2000 orang yang tinggal di daerah rawan banjir dan 4040 orang tinggal di daerah yang rawan air bersih.

Solusi dari permasalahan tersebut, diharapkan dapat diperhatikan kembali dari pendapatan perkapita melalui sektor pertanian yang hanya Rp.50.000 per rumah tangga, lalu ditambahkan lagi untuk taman bacaan bagi warga setempat kemudian ditingkatkan dalam pengisian data pada lama Prodeskel. Kemudian pihak desa bisa melakukan relokasi bagi para warga setempat yang meninggali daerah rawan banjir dan juga pihak desa dapat bekerja sama dengan pihak terkait untuk menangani permasalahan daerah yang rawan air bersih. Potensi yang terpampang sangat jelas pada desa Tambaksumur adalah pada sektor pertanian. Luas tanah persawahan mencapai 620.000 Ha yang ini merupakan potensi yang sangat besar. Hal ini seharusnya dapat dikembangkan oleh Pihak desa agar dapat dijadikan sebagai salah satu cara untuk menaikan pendapatan perkapita bagi setiap rumah tangga warga setempat. 


\section{KESIMPULAN DAN SARAN}

Kuliah Kerja Nyata (KKN) "profil desa dan kelurahan untuk tujuan pembangunan berkelanjutan (TPB)" UBP karawang merupakan kegiatan yang digunakan untuk proses pembelajaran mahasiswa sekaligus pemberdayaan masyarakat dan kegiatan ini adalah kali ke-3 yang dilakukan oleh UBP karawang selaku institusi Pendidikan Perguruan Tinggi Swasta dalam menjawab tantangan zaman saat ini. Mahasiswa selaku subjek yang melaksanakan KKN ini dituntut untuk menggali potensi masing-masing desa untuk selanjutnya memberikan kontribusi bagi perkembangan desa lebih baik.

Pelaksanaan program KKN di Desa Tambak Sumur ,Kecamatan Tirtajaya,Kabupaten Karawang. Selama 1 bulan diterjunkan tanggal 1 agustus 2020 sampai dengan tanggal 31 agustus. Dari hasil data-data yang telah diambil dapat dikesimpulan sebagai berikut :

1. Ekonomi Masyarakat Desa Tambak Sumur bergantung kepada sumber pertanian. Karena Tambaksumur memiliki luas tanah persawahan sebesar $620.000 \mathrm{Ha}$ dan memiliki 3.080 Kepala keluarga yang bermata-pencarian pada pertanian tetapi berbanding terbalik dengan kecilnya pendapatan bagi sektor pertanian per rumah tangga yaitu Rp.50.000.

2. Sumber Daya Alam Desa Tambak Sumur sebenarnya sangat melimpah ruah, tetapi yang menjadi kendala di desa tersebut adalah kurangnya Sumber Daya Manusia yang memadai.

3. Partisipasi masyarakat sangat dibutuhkan dalam upaya pembangunan sebuah desa, tanpa adanya pertisipasi dari masyarakat maka desa tersebut akan sangat sulit untuk berkembang sehingga akan menimbulkan ketidak sejahteraan dalam lingkungan masyarakat desa tersebut.

Diharapkan perangkat desa dapat membuat pelatihan dan pembimbingan dalam meningkatkan kualitas sumber daya manusia yang ada di Desa Tambak Sumur supaya Sumber Daya Alam yang dimiliki desa tersebut dapat dimanfaatkan untuk kesejahteraan masyarakat desa tersebut. Dalam hal pelatihan dan pembinaan, pihak desa dapat bekerja sama dengan Dinas Pemberdayaan8 Masyarakat dan Desa Kabupaten Karawang sebagai mentor desa. Perangkat Desa hendaknya mengerti bahwa kegiatan 
KKN bukan hanya untuk kepentingan mahasiswa saja tetapi kepentingan masyarakat desa setempat, dimana mahasiswa hanya sebagai motivator yang membantu memecahkan masalah sehingga diharapkan partisipasi masyarakat dalam setiap program kerja KKN dapat lebidalam setiap program kerja KKN dapat lebih tinggi.

\section{DAFTAR PUSTAKA}

http://prodeskel.binapemdes.kemendagri.go.id/mpublik/

https://id.wikipedia.org/wiki/Tambaksumur, Tirtajaya, Karawang

https://karawangkab.bps.go.id/publication.html 